\title{
ANALISIS REFERENSI SISWA SEKOLAH MENENGAH KEJURUAN DALAM MEMILIH PROGRAM STUDI DI PERGURUAN TINGGI
}

\author{
Urzu Rahmad \\ SMP Negeri 3 Sumbermanjing Wetan, \\ Jalan Raya Tambakasri, Sumber Manjing Wetan, Malang \\ Email: urzupoachers@gmail.com
}

\begin{abstract}
The purpose of this study is to find out how many references obtained by students to recognize the study program that will be selected, how much contribution from each reference that affects students in choosing courses in college, and which reference sources are the greatest effect on students in election course. This research uses a quantitative approach with descriptive-explorative design. The population of this study as many as 3.643 students with a sample of 331 students obtained through the technique proportional random sampling. Data were collected through a questionnaire of 31 questions. The result of this research are: (1) reference source obtained by students to choose study program in college that is: family impulse factor, mass media factor, personal interest factor, and environmental factor; (2) contribution of each reference source start from smallest to the largest, as follows: environmental factors, personal interest factors, mass media factors, and family encouragement factors; and (3) the greatest reference source of influence on the selection of courses is the factor of family encouragement.
\end{abstract}

Keywords: references students, election courses, colleges

\begin{abstract}
Abstrak: Tujuan penelitian ini adalah untuk mengetahui seberapa banyak referensi yang diperoleh siswa guna mengenali program studi yang akan dipilihnya, seberapa besar kontribusi dari masing-masing referensi yang mempengaruhi siswa dalam memilih program studi di perguruan tinggi, dan sumber referensi mana yang paling besar pengaruhnya terhadap siswa dalam pemilihan program studi. Penelitian ini menggunakan pendekatan kuantitatif dengan rancangan deskriptif-eksploratif. Populasi penelitian ini sebanyak 3.643 siswa dengan sampel penelitian 331 siswa yang didapat dengan melalui teknik proportional random sampling. Data dikumpulkan melalui angket yang berjumlah 31 pertanyaan. Hasil penelitian ini adalah: (1) sumber referensi yang diperoleh siswa untuk memilih program studi di perguruan tinggi yaitu: faktor dorongan keluarga, faktor media massa, faktor kepentingan pribadi, dan faktor lingkungan; (2) kontribusi masing-masing sumber referensi mulai dari terkecil hingga terbesar, sebagai berikut: faktor lingkungan, faktor kepentingan pribadi, faktor media massa, dan faktor dorongan keluarga, dan (3) sumber referensi yang paling besar pengaruhnya terhadap pemilihan program studi adalah faktor dorongan keluarga.
\end{abstract}

Kata kunci : referensi siswa, pemilihan program studi, perguruan tinggi

Era sekarang ini keunggulan dari suatu bangsa tidak lagi hanya mengandalkan pada kekayaan alam yang dimilikinya, melainkan pada keunggulan sumber daya manusia. Perencanaan peserta didik yang matang dapat menghasilkan lulusan yang baik. Perencanaan peserta didik adalah suatu aktivitas memikirkan di mukatentang hal-hal yang harus dilakukan berkenaan dengan peserta didik di sekolah, baik sejak peserta didik akan memasuki sekolah maupun mereka yang akan lulus dari sekolah (Imron, 2012; Gunawan dan Benty, 2017). Dengan perencanaan yang baik akan menghasilkan lulusan-lulusan yang kompeten yang akan dapat menjawab semua kebutuhan yang ada di kehidupan nyata secara cepat. Sekolah merupakan jalur pendidikan formal yang memiliki berbagai jenjang, yaitu taman kanak-kanak (TK), sekolah dasar (SD), sekolah menengah pertama (SMP), sekolah menengah atas (SMA), dan perguruan tinggi 
(PT). SMA adalah bentuk pendidikan menengah yang merupakan lanjutan dari pendidikan dasar yang terdiri dari pendidikan menengah umum dan pendidikan menengah kejuruan.

Pada tahun ajaran baru, banyak siswa Kelas XII Sekolah Menengah Kejuruan (SMK) yang akan melanjutkan studi ke perguruan tinggi. Tetapi, siswa dihadapkan pada pilihan yang sulit, yaitu memilih jurusan. Apakah siswa akan melanjutkan sesuai jurusan pada saat SMK atau memilih jurusan lain. Akan tetapi, kebanyakan siswa SMK, terutama yang tidak memiliki referensi dan malas untuk mencari informasi terkait dengan jurusan yang akan dipilihnya pada saat menempuh pendidikan di perguruan tinggi. Mengenali jurusan yang akan dimasuki sejak dini, dimaksudkan untuk memudahkan siswa memilih bidang ilmu yang akan ditekuninya di perguruan tinggi yang akan mengarah pula kepada karirnya kelak. Akan tetapi, jurusan di tingkat SMK tidak selalu menjamin, bahwa seorang siswa akan memilih bidang studi yang sama di perguruan tinggi. Hal yang wajar pemilihan jurusan yang berbeda pada saat studi di perguruan tinggi dengan jurusan yang ditekuni di SMK itu wajar.

Seyogyanya pada jenjang pendidikan di SMK siswa terus fokus pada jurusannya agar saat melanjutkan ke PT tidak lagi salah pilih jurusan. Jurusan di perguruan tinggi sangat beragam, sehingga calon mahasiswa harus memilih dari berbagai macam jurusan yang masih belum diketahui, kecuali jurusan yang sama pada saat masih pada jenjang pendidikan di SMK. Dari data jurusan yang ada di Universitas Negeri Malang, siswa dapat menentukan jurusan yang akan dipilihnya. Sebagai contoh bahasan, yaitu Fakultas Ilmu Pendidikan (FIP), bertujuan untuk mencetak para tenaga kependidikan yang kompeten dan berkualitas, sedangkan Fakultas Ekonomi (FE) berorientasi mencetak sarjana yang mampu menjadi tenaga pendidik dan wirausaha yang terjun pada dunia ekonomi. Akan tetapi masih banyak siswa yang memilih jurusan hanya ikut-ikutan dan menuruti keluarga.

Seharusnya mahasiswa mengetahui jurusan yang dipilihnya pada proses atau sebelum pendaftaran. Oleh karena itu siswa yang masih duduk di Kelas XII SMK harus terlebih dahulu mengetahui jurusan yang akan dipilihnya, agar pada saat studi di perguruan tinggi sudah tidak lagi mempersoalkan tentang jurusan yang dipilihnya dan tidak mengkambinghitamkan jurusannya apabila ternyata jurusannya kurang familiar di kalangan masyarakat. Kurikulum SMK dirancang untuk menghasilkan lulusan guna menyiapkan tenaga kerja. Hal ini senada dengan Undang-undang Nomor 20 tahun 2003 tentang Sistem Pendidikan Nasional yang menyatakan pendidikan kejuruan merupakan pendidikan menengah yang mempersiapkan peserta didik terutama untuk berkerja dalam bidang tertentu. Namun demikian, dalam kenyataannya tidak sedikit lulusan SMK yang melanjutkan ke perguruan tinggi. Dari semua siswa SMK ada yang melanjutkan ke perguruan tinggi. Dengan mengetahui jurusan di perguruan tinggi siswa akan lebih mudah dalam mengikuti proses perkuliahan dan tidak mengalami hambatan yang cukup berarti.

Motivasi intrinsik mengacu pada motivasi melibatkan diri dalam sebuah aktivitas karena nilai atau manfaat aktivitas itu sendiri, dan aktivitas itu sendiri merupakan sebuah tujuan akhir (Schunk, 2012; Gunawan dan Benty, 2007). Motivasi intrinsik yaitu motif-motif yang menjadi aktif atau berfungsi yang tidak perlu dirangsang lagi (Djamarah, 1994). Motivasi intrinsik mengacu pada keinginan untuk melakukan aktivitas bukan untuk mendapat hadiah melainkan pengerjaan tugas itu sendiri (Schunk, 2012). Berdasarkan beberapa definisi tersebut dapat disimpulkan motivasi intrinsik adalah motivasi yang menjadi aktif karena keinginan untuk melakukan aktivitas guna mendekatkannya dengan tujuan akhir.

Motivasi ekstrinsik adalah kebalikan dari motivasi intrinsik yaitu motif-motif yang aktif dan berfungsi karena adanya rangsangan dari luar (Djamarah, 1994). Motivasi yang disebabkan oleh keinginan untuk menerima ganjaran atau menghindari hukuman (Uno, 2006; Gunawan, 2014). Dari penjelasan tersebut dapat disimpulkan motivasi eksternal bersumber akibat pengaruh dari luar individu, bisa berupa ajakan, paksaan, sehingga dengan keadaan seperti ini siswa dengan terpaksa akan memilih jurusan yang tidak sesuai dengan kehendaknya. Hal ini akan berdampak negatif apabila siswa tidak merasa nyaman pada jurusan yang dipilihnya.

Reference group adalah kelompok yang digunakan sebagai alat ukur untuk menilai diri sendiri atau untuk membentuk sikap (Setiadi, 2013). Dalam kelompok ini melibatkan satu 
orang atau lebih yang dijadikan referensi dalam membentuk tanggapan afektif dan kognitif serta menyatakan perilaku seseorang. Kelompok referensi (reference group) adalah seorang individu atau sekelompok orang yang secara nyata mempengaruhi perilaku seseorang. Dengan demikian kelompok referensi adalah kelompok yang digunakan sebagai alat ukur untuk membentuk sikap secara afektif, kognitif, dan psikologis.

Memilih jurusan pada perguruan tinggi harus mempertimbangkan pilihan yang akan diambilnya, dalam menentukan pilihan tersebut dapat berorientasi pada salah satu teori, yaitu teori rational choice. Orang bertindak untuk mengejar kepentingan pribadi mereka, melalui mekanisme the invisible hand guna menghasilkan keuntungan. Penekanan pada agen juga tidak serta merta pendekatan rational choice mengabaikan variabel sosial atau kolektif yang membatasi pilihan-pilihan individu (Tapiheru, 2016). Secara implisit maupun eksplisit banyak para pengusut teori ini yang mengakui bahwa sesungguhnya individu-individu ini bertindak secara rasional ketika mereka dirangsang oleh stimulus tertentu, dan pilihan-pilihan mereka juga terbatas. Stimulus dan pilihan ini bervariasi untuk tiap individu, bergantung pada sistem dimana individu-individu itu berada.

Berdasarkan pendapat di atas dapat disimpulkan, bahwa rational choice adalah tata cara individu dalam memutuskan sebuah pilihan yang berdasarkan kecenderungan pribadi, ketika individu ini dirangsang oleh stimulus tertentu, dan pilihan-pilihan individu ini pun terbatas. Jika dikaitkan dengan penelitian, maka rational choice ini dimiliki oleh siswa SMK dalam menentukan jurusan apa yang akan diambil ketika melanjutkan ke perguruan tinggi. Jurusan-jurusan di perguruan tinggi yang dapat dikatakan terbatas, dimana juga bergantung pada jenis perguruan tingginya, inilah yang akan mendorong siswa untuk memilih secara rasional jurusan yang akan dipilihnya.

\section{METODE}

Pendekatan yang digunakan dalam penelitian ini adalah pendekatan kuantitatif dengan metode deskriptif-eksploratif. Populasi penelitian ini yaitu siswa SMK Negeri dan Swata di Kabupaten Malang bagian selatan. Jumlah populasinya adalah 3.643 siswa yang tersebar di 20 SMK Negeri dan Swasta di Kabupaten Malang bagian selatan. Penelitian ini menggunakan teknik pengambilan sampel proportional random sampling. Populasi 3.643 orang siswa diambil 331 orang siswa yang dijadikan sampel dalam penelitian ini. Teknik pengambilan data penelitian ini dengan menggunakan angket tertutup. Analisis data dengan menggunakan analisis deskriptif dan analisis faktor guna mengetahui faktor atau referensi mana yang paling mempengaruhi siswa dalam memilih program studi di perguruan tinggi.

\section{HASIL}

Setelah melakukan penelitian kepada 331 siswa SMK Negeri dan Swasta di Kabupaten Malang bagian selatan. Responden terdiri dari 184 siswa berjenis kelamin laki-laki dan 147 siswa berjenis kelamin perempuan. Serta terdapat 13 jurusan yang ada di sekolah yang menjadi tempat penelitian. Hasil yang didapat dari hasil uji interkorelasi antar item-item pernyataan yang berjumlah 31 , tidak ada butir yang digugurkan, karena nilainya tidak ada yang lebih tinggi dari 0,08 . Hal ini juga didukung oleh hasil pengukuran menggunakan measure of samplinh adequacy (MSA). Dari 31 butir item yang ada tidak ada butir yang dibawah 0,50 sehingga butirbutir pernyataan tidak perlu digugurkan, dan dapat langsung melakukan analisis faktor secara eksploratif terhadap 31 item.

Hasil analisi faktor menunjukkan, bahwa terdapat 4 faktor baru hasil rotasi. Empat faktor baru atau sumber referensi yang digunakan siswa yaitu: (1) faktor dorongan keluarga yang terdiri dari 11 pernyataan dan memiliki eigen value $18,915 \%$; (2) faktor media massa terdiri dari 9 pernyataan dan memiliki eigen value $10,901 \%$; (3) faktor kepentingan pribadi terbentuk dari 8 pernyataan serta memiliki eigen value $5,856 \%$; dan (4) faktor lingkungan masyarakat terdiri dari 3 pernyataan serta memiliki eigen value $5,217 \%$. Kontribusi masing-masing faktor ditampilkan pada Tabel 1 . 
Tabel 1 Kontribusi Masing-Masing Faktor

\begin{tabular}{|c|c|c|c|c|}
\hline \multirow{2}{*}{ Faktor } & \multirow{2}{*}{$\begin{array}{c}\text { Eigen } \\
\text { Value }\end{array}$} & \multicolumn{3}{|c|}{ Kategori } \\
\cline { 3 - 5 } & Tinggi & Sedang & Rendah \\
\hline $\begin{array}{c}\text { Dorongan } \\
\text { keluarga }\end{array}$ & $18,915 \%$ & $52,6 \%$ & $46,8 \%$ & $0,6 \%$ \\
\hline $\begin{array}{c}\text { Media } \\
\text { massa }\end{array}$ & $10,901 \%$ & $28,7 \%$ & $63,7 \%$ & $7,6 \%$ \\
\hline $\begin{array}{c}\text { Kepentingan } \\
\text { pribadi }\end{array}$ & $5,856 \%$ & $52,6 \%$ & $46,8 \%$ & $0,6 \%$ \\
\hline $\begin{array}{c}\text { Lingkungan } \\
\text { masyarakat }\end{array}$ & $5,217 \%$ & $24,8 \%$ & $64,4 \%$ & $10,9 \%$ \\
\hline
\end{tabular}

Berdasarkan Tabel 1 dapat diketahui bahwa terdapat salah satu faktor yang paling dominan dari faktor yang lainnya dan faktor ini diberi nama faktor dorongan keluarga. Faktor dorongan keluarga masuk dalam kategori tinggi dan memiliki eigen value sebesar $18,915 \%$ yang terdiri dari 11 pertanyaan. Distribusi frekuensi pada kategori tinggi sebanyak 174 siswa atau sebesar 52,6\%; kategori sedang sebanyak 155 siswa atau sebesar $46,8 \%$; dan pada kategori rendah sebanyak 2 siswa atau sebesar $0,6 \%$. Dapat ditarik kesimpulan, bahwa persentase faktor dorongan keluarga dalam kategori tinggi sebanyak 174 siswa atau sebesar 52,6\%.

Penelitian ini mengungkapkan empat faktor baru hasil analisis mengenai referensi siswa SMK di Kabupaten Malang bagian selatan dalam memilih program studi di perguruan tinggi di Kota Malang. Dari keempat faktor yang telah dibahas nilai eigen value terbesar yaitu dorongan keluarga. Faktor ini mengelompok pada indikator keluarga. Indikator ini memiliki arti, bahwa siswa dalam memilih program studi di perguruan tinggi atas dorongan dari keluarganya. Faktor dorongan keluarga ini merupakan faktor utama yang dijadikan siswa sebagai sumber referensi untuk memilih program studi di perguruan tinggi.

\section{PEMBAHASAN}

Hasil pengolahan data pada bab sebelumnya dapat diketahui, bahwa terdapat empat faktor baru yang muncul, di antaranya faktor dorongan keluarga, faktor media massa, faktor kepentingan pribadi, dan faktor lingkungan. Pada faktor dorongan keluarga memiliki eigen value terbesar mengelompok pada indikator keluarga.
Selanjutnya faktor media massa nilai eigen value terbesar mengelompok pada indikator masyarakat maya. Faktor kepentingan pribadi nilai eigen value terbesar pada indikator tantangan, dan faktor lingkungan nilai eigen value terbesar mengelompok pada indikator orang biasa.

Faktor dorongan keluarga terwakili dari 11 pernyataan, setelah mengelompok menjadi konsep baru yang diberi nama faktor dorongan keluarga dan memiliki eigen value 18,915\%. Indikator ini memiliki arti, dorongan dari keluarga berkontribusi bagi siswa dalam memilih program studi di perguruan tinggi. Pernyataan tersebut senada dengan Mangkunegara (2002) yang menyatakan bahwa keluarga didefinisikan sebagai suatu unit terkecil masyarakat yang perilakunya sangat mempengaruhi dan menentukan dalam pengambilan keputusan. Dengan demikian siswa memilih program studi di perguran tinggi karena adanya rangsangan dari luar dirinya yang sangat signifikan dalam pengambilan keputusan.

Beberapa penelitian yang mendukung tentang dorongan keluarga salah satunya yaitu oleh Ester dan Bowen yang menyimpulkan: (1) orangtua merupakan faktor pertama yang berpengaruh terhadap pilihan karir anak mereka; dan (2) pekerjaan orangtua berhubungan dengan signifikan dengan pilihan karir anak-anak mereka (Purwanta, 2013). Dengan kata lain orangtua berinteraksi dengan anak-anak mereka mengenai isu-isu yang terkait dengan karier anggota keluarga lainnya sebagai informasi bagi siswa dalam mengambil keputusan.

Faktor dorongan keluarga ini merupakan faktor utama yang menjadi alasan siswa dalam memilih program studi di perguruan tinggi. Hasil analisis data menunjukkan bahwa sebanyak 174 siswa atau 52,6\% dari keseluruhan responden dalam pemilihan program studi didasari oleh faktor dorongan keluarga. Berdasarkan hasil analisis data tersebut, dapat disimpulkan bahwa, referensi siswa SMK di Kabupaten Malang bagian selatan dalam memilih program studi di perguruan tinggi di Kota Malang disebabkan oleh faktor dorongan keluarga, yang mana siswa dalam memilih program studi selalu mengedepankan pendapat keluarganya.

Kelompok faktor media massa terwakili oleh 9 pernyataan, yang kemudian mengelompok menjadi konsep baru dengan nama faktor media massa dan memiliki eigen value sebesar 
10,901\%. Dalam memilih program studi media massa menjadi salah satu sumber siswa untuk mengetahui profil dari sebuah program studi di perguruan tinggi. Penjelasan tersebut sesuai dengan pernyataan Schiffman dan Kanuk (2008) yang menyatakan berkat komputer dan internet, orang dapat menyaksikan awal terbentuknya tipe kelompok baru. Baik dewasa maupun anak-anak membuka komputer mereka, mencatat di web, dan mengunjungi berbagai situs web khusus, dan membuka chat room. Kelompok ini akan berpengaruh terhadap individu-individu yang kurang bersosialisasi di dunia nyata. Periklanan adalah segala bentuk presentasi dan promosi gagasan, barang atau jasa oleh sponsor tertentu yang harus dibayar (Kotler, 2010; Benty dan Gunawan, 2015).

Saat ini, banyak iklan dibuat di media massa agar perguruan tinggi dapat menyampaikan informasi secara efektif dan efsian. Dengan demikian siswa yang kurang bersosialisasi di dunia nyata cenderung menggunakan sumber referensi dari media massa baik itu dari internet atau media cetak guna mengetahui kelebihan dan kekurangan suatu program studi di perguruan tinggi. Hasil analis data menunjukkan bahwa sebanyak 211 siswa atau sebesar $63,7 \%$ dari keseluruhan responden dalam pemilihan program studi didasari oleh faktor media masa. Berdasarkan hasil analisis data tersebut, dapat disimpulkan bahwa, referensi siswa SMK di Kabupaten Malang bagian selatan dalam memilih program studi di perguruan tinggi di Kota Malang disebabkan oleh faktor media massa, yang mana siswa dalam memilih program studi mendapat referensi dari media massa yang memuat profil dari setiap program studi di perguruan tinggi.

Faktor kepentingan pribadi terwakili oleh 8 item pernyataan, setelah mengelompok menjadi konsep baru diberi nama faktor mengembangkan potensi diri dan memiliki eigen value sebesar $5,856 \%$. Pada faktor kepentingan pribadi dapat diartikan, bahwa siswa merasa memiliki suatu kepentingan atau tujuan tertentu dalam memilih program studi di perguruan tinggi. Dengan demikian, kepentingan pribadi dapat terwujud ketika siswa mempertimbangkan program studi yang memiliki trek rekor yang bagus. Faktor kepentingan pribadi ini merupakan faktor ketiga yang menjadi sumber referensi siswa dalam memilih program studi di perguruan tinggi. Hasil analis data menunjukkan bahwa sebanyak 174 siswa atau sebesar 52,6\% dari keseluruhan responden dalam pemilihan program studi didasari oleh faktor kepentingan pribadi. Berdasarkan hasil analisis data tersebut, dapat disimpulkan bahwa, referensi siswa SMK di Kabupaten Malang bagian selatan dalam memilih program studi di perguruan tinggi di Kota Malang disebabkan oleh faktor kepentingan pribadi, yang mana siswa dalam memilih program studi memiliki kepentingan atau tujuan tertentu dalam benaknya.

Kelompok faktor lingkungan masyarakat terwakili oleh 3 item pernyataan, setelah mengelompok konsep baru ini diberi nama faktor lingkungan dan memiliki eigen value sebesar 5,217\%. Pada faktor lingkungan dapat diartikan, bahwa siswa dalam memilih program studi di perguruan tinggi dikarenakan pengaruh dari lingkungannya tinggal. Penjelasan tersebut sejalan dengan pendapat Danusaputra (2006) yang menyatakan lingkungan masyarakat adalah lingkungan yang didalamnya terdapat manusia dan aktifitasnya. Lingkungan masyarakat mempengaruhi kesejahteraan manusia dan tingkah laku manusia yang tinggal di dalamnya. Dengan demikian dapat disimpulkan bahwa faktor lingkungan dapat terwujud karena ketika siswa mempertimbangkan pendapat dari masyarakat sekitar rumahnya untuk program studi yang akan dipilihnya.

Hasil analis data menunjukkan bahwa sebanyak 213 siswa atau sebesar $64,4 \%$ dari keseluruhan responden dalam pemilihan program studi didasari oleh faktor lingkungan. Berdasarkan hasil analisis data tersebut, dapat disimpulkan bahwa, referensi siswa SMK di Kabupaten Malang bagian selatan dalam memilih program studi di perguruan tinggi di Kota Malang disebabkan oleh faktor lingkungan, yang mana siswa mempertimbangkan pendapat dari masyarakat sekitar rumahnya untuk program studi yang akan dipilihnya.

\section{KESIMPULAN DAN SARAN}

\section{Kesimpulan}

Berdasarkan hasil penelitian dan pembahasan temuan hasil penelitian dapat diperoleh kesimpulan: (1) sumber referensi siswa dalam memilih program studi di perguruan 
tinggi, yaitu faktor dorongan keluarga, faktor media massa, faktor kepentingan pribadi, dan faktor lingkungan; (2) kontribusi masing-masing sumber referensi mulai dari yang terbesar hingga terkecil, yaitu faktor dorongan keluarga, faktor media massa, faktor kepentingan pribadi, dan faktor lingkungan; dan (3) faktor paling dominan yang menjadi sumber referensi siswa dalam memilih program studi di perguruan tinggi adalah faktor dorongan keluarga.

\section{Saran}

Saran dalam penelitian ini ditujukan kepada: (1) Kepala SMK Kabupaten Malang hendaknya memperhatikan kebutuhan siswa ketika mereka berkeinginan untuk melanjutkan ke jenjang yang lebih tinggi dengan memberikan bimbingan dan pengarahan untuk memudahkan siswa dalam memilih program studi di perguruan tinggi; (2) sebaiknya siswa SMK mempertimbangkan dengan matang saran yang diberikan oleh keluarga, lingkungan sekitar, guru, dan informasi yang dimuat media agar dapat lebih mendekatkan pada cita-cita yang akan dicapainya kelak; (3) perguruan tinggi hendaknya memberikan informasi mengenai program studi yang ada dengan rinci, dengan memuat profil program studi di website resmi perguruan tinggi dan media cetak, agar siswa dapat mengenali program studi dengan baik; dan (4) bagi peneliti lain sebaiknya melakukan kajian ulang terhadap penelitian ini.

\section{DAFTAR RUJUKAN}

Benty, D. D. N., dan Gunawan, I. 2015. Manajemen Hubungan Sekolah dan Masyarakat. Malang: Universitas Negeri Malang, UM Press.

Danusaputra, M. 2006. Hukum Lingkungan. Bandung: Binacipta.

Djamarah, S. B. 1994. Strategi Belajar Mengajar. Bandung: Rineka Cipta.

Gunawan, I. 2014. Pengaruh Supervisi Pengajaran dan Kemampuan Guru Mengelola Kelas terhadap Motivasi Belajar Siswa. Ilmu Pendidikan Jurnal Kajian Teori dan Praktik Kependidikan, 41(1), 44-52.

Gunawan, I., dan Benty, D. D. N. 2007. Musyawarah Guru Mata Pelajaran dan Kemampuan Mengelola Kelas untuk Meningkatkan Motivasi Belajar Siswa. Manajemen Pendidikan, 20(1), 21-31.

Gunawan, I., dan Benty, D. D. N. 2017. Manajemen
Pendidikan: Suatu Pengantar Praktik. Bandung: Alfabeta.

Imron, A. 2012. Manajemen Peserta Didik Berbasis Sekolah. Jakarta: PT Bumi Aksara.

Kotler, P. 2010. Marketing Management. New Jersey: Pearson.

Mangkunegara, A. P. 2002. Manajemen Sumber Daya Manusia. Jakarta: PT Remaja Rosda Karya.

Purwanta, E. 2013. Dukungan Keluarga Orangtua dalam Karier terhadap Perilaku Eksplorasi Karier Siswa SMP. Jurnal Teknodika, 10, 127-140.

Schiffman, L., dan Kanuk, L. L. 2008. Perilaku Konsumen. Terjemahan oleh Sarwiji. Jakarta: PT Indeks.

Schunk, D. H. 2012. Teori-Teori Pembelajaran: Perspektif Pendidikan. Terjemahan oleh Eva Hamidah dan Rahmat Fajar. Yogyakarta: Pustaka Pelajar.

Setiadi, N. J. 2013. Perilaku Konsumen: Perspektif Kontemporer pada Motif, Tujuan, dan Keinginan Konsumen. Jakarta: Kencana Prenada Media Group.

Tapiheru, J. 2016. Rational-Choice Theory. (Online), (http://elisalugm.ac.id/files/

PSantoso_Isipol/1VqiBwkh/RATIONAL $\% 20$ CHOICE\%20THEORY.pdf), diakses 5 Oktober 2016.

Uno, H. B. 2006. Orientasi Baru dalam Psikologi Pembelajaran.Jakarta: PT Bumi Aksara. 